\title{
Herero Language
}

National Cancer Institute

\section{Source}

National Cancer Institute. Herero Language. NCI Thesaurus. Code C153946.

A Niger-Congo Bantu language spoken by the Herero and Mbanderu peoples in Namibia and Botswana. 